\title{
Odontoma pada anjing Siberian husky
}

\author{
Muhamad Arfan Lesmana*, Ulvi Hudriyah, Albiruni Haryo, Fathinah Inas Hutasuhut \\ Departemen Klinik Hewan Pendidikan, Fakultas Kedokteran Hewan, Universitas Brawijaya, Malang
}

\begin{abstract}
ABSTRAK: Anjing betina dengan ras Siberian husky bernama Hugo berumur 12 tahun dibawa ke Rumah Sakit Hewan Pendidikan, Fakultas Kedokteran Hewan, Universitas Brawijaya dengan keluhan terdapat daging atau massa pada daerah gusi, hal tersebut sudah berlangsung selama \pm 1 bulan, namun anjing tersebut masih mau makan. Pemeriksaan fisik didapati bahwa suhu tubuh anjing $38,9{ }^{\circ} \mathrm{C}$ dan detak jantung $100 \mathrm{x} /$ menit, serta ditemukan adanya massa berukuran sedang pada gusinya, terdapat banyak karang gigi dan nafas bau. Hasil pemeriksaan radiografi menunjukkan adanya radioopacity pada daerah mandibula dexter. Hasil pemeriksaan darah menunjukkan leukositosis, limfositosis dan monositosis sebagai indikasi terjadi inflamasi. Diagnosis penyakit pasien ini adalah odontoma. Terapi dilakukan dengan tindakan bedah ekstirpasi massa, pencabutan gigi disekitarnya dan pembersihan karang gigi. Pascabedah diberikan antiseptik, kortikosteroid dan suplemen, serta anjing diperbolehkan untuk pulang setelah 1 hari perawatan pascabedah karena kondisi sudah membaik.
\end{abstract}

\section{Kata kunci:}

odontoma, bedah ekstirpasi, anjing Siberian husky

\section{- PENDAHULUAN}

Odontoma dalam dunia kedokteran dan kedokteran gigi pada awalnya digunakan untuk setiap tumor dan/ atau lesi seperti tumor, seperti kista neoplastik yang timbul dari jaringan pembentuk gigi (Kharbanda et al. 1986). Odontoma berkembang dari jaringan odontogenik primordial. Komposisinya adalah kombinasi dari epitel odontogenik dan ektomesenkim odontogenik. Biasanya tumor ini tidak bergejala (Barnes et al. 2005). Kejadian odontoma kompleks dapat diamati massa radioopak amorf, juga dikelilingi oleh zona radiolusen yang sempit (Jaeger et al. 2012). Laporan kasus dan penanganan odontoma pada anjing di Indonesia hingga saat ini masih sulit ditelusuri. Tulisan ini melaporkan penanganan kejadian odontoma pada seekor anjing Siberian husky yang ditangani di Rumah Sakit Hewan Pendidikan, Fakultas Kedokteran Hewan, Universitas Brawijaya, Malang.

\section{- KASUS}

Sinyalemen, anamnesa, dan gejala klinis: seekor anjing ras Siberian husky bernama Hugo berumur 12 tahun berjenis kelamin betina dengan rambut berwarna hitam dan putih dibawa ke Rumah Sakit Hewan Pendidikan Universitas Brawijaya (RSHP UB) pada tanggal 12 September 2019. Kondisi terdapat daging atau massa pada daerah gusi, hal tersebut sudah berlangsung selama \pm 1 bulan, namun anjing tersebut masih mau makan.

Pemeriksaan fisik: Anjing Hugo menunjukkan suhu tubuh $38,9^{\circ} \mathrm{C}$ dan detak jantung $100 \mathrm{x} /$ menit. Inspeksi pada daerah rongga mulut ditemukan massa berukuran sedang pada derah mandibula dexter, terdapat banyak karang gigi dan nafas bau (Gambar 1).

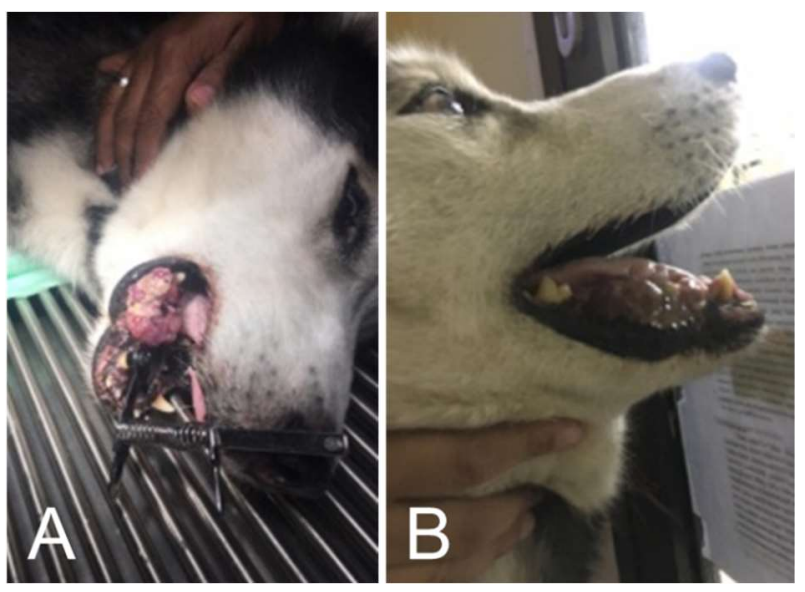

Gambar 1. Odontoma pada anjing Hugo, (A) tampak depan berbaring dan (B) tampak samping.

Diagnosa penunjang: Hasil pemeriksaan pada citra radiografi menunjukkan adanya odontoma pada mandibula dexter (Gambar 2). Hasil pemeriksaan hematologi dan kimia darah menunjukkan adanya leukositosis, limfositosis, dan monositosis yang mengindikasikan terjadi inflamasi dan infeksi (bakteri, virus ataupun parasit). Adanya peningkatan ALT sebagai indikator sensitif dari kerusakan sel hati, ALP meningkat karena induksi obat-obatan tertentu, penurunan nilai albumin tidak signifikan mengindikasikan penurunan fungsi hati, kehilangan darah atau penyakit ginjal. Nilai globulin meningkat sebagai indikasi terjadi infeksi kronis dan peradangan terutama pada area rongga mulut (Tabel 1).

Diterima: 10-08-2020 | Direvisi: 11-10-2020 | Disetujui: 15-10-2020

(C) 2020 CC-BY-SA. Ini adalah artikel Open Access yang didistribusikan berdasarkan ketentuan dari Creative Commons Attribution ShareAlike 4.0 International License (https://creativecommons.org/licenses/by-sa/4.0/). 


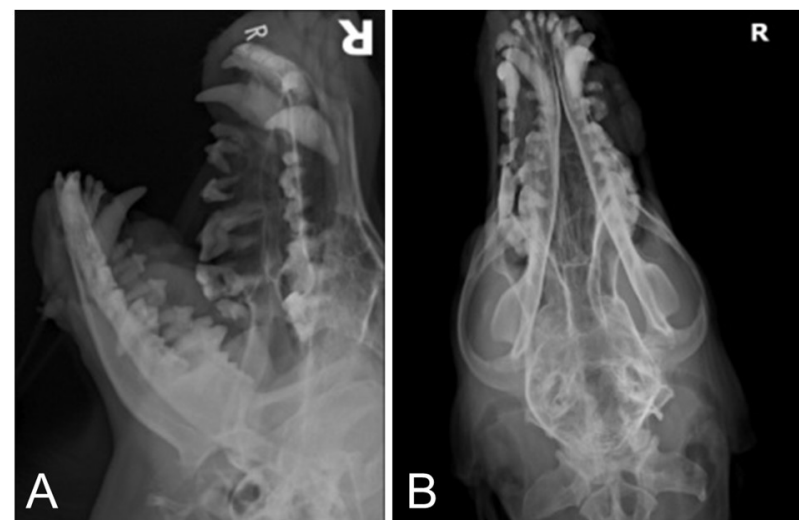

Gambar 2. X-ray pasien (A) Cranial posisi Right Lateral (RL) dan (B) Cranial posisi Dorso Ventral (DV) terlihat adanya radioopacity pada daerah manibula dexter.

Diagnosa, prognosa dan terapi: Berdasarkan anamnesa, status present dan hasil pemeriksaan penunjang maka anjing bernama Hugo didiagnosa odontoma. Prognosanya dubius. Terapi yang dilakukan adalah bedah ekstirpasi massa, pencabutan gigi disekitarnya dan pembersihan karang gigi (scalling). Terapi pascabedah yang diberikan adalah minosep + oxyfresh bid, bufacomp bid, Sangobion ${ }^{\circledR} 1$ cap s1dd, dan Yunnan Baiyao ${ }^{\circledR} 1$ cap s1dd.

Tabel 1. X Hasil uji hematologi dan kimia darah.

\begin{tabular}{|ccccc|}
\hline Parameter & Satuan & Hasil & Standar & Keterangan \\
\hline $\mathrm{WBC}$ & $10^{3} / \mathrm{uL}$ & 18,8 & $6,0-7,0$ & Tinggi \\
$\mathrm{RBC}$ & $10^{6} / \mathrm{uL}$ & 5,23 & $5,5-8,5$ & Rendah \\
$\mathrm{Hb}$ & $\mathrm{g} / \mathrm{dL}$ & 4,9 & $12,0-18,0$ & Rendah \\
$\mathrm{HCT}$ & $\%$ & 32,3 & $37,0-55,0$ & Rendah \\
$\mathrm{MCV}$ & $\mathrm{fL}$ & 61,8 & $60,0-77,0$ & Normal \\
$\mathrm{MCH}$ & $\mathrm{pg}$ & 9,4 & $19,5-24,5$ & Rendah \\
$\mathrm{MCHC}$ & $\mathrm{g} / \mathrm{dL}$ & 15,2 & $32,2-36,0$ & Rendah \\
Platelet & $103 / \mathrm{uL}$ & 334 & $200-500$ & Normal \\
Granulosit & $\%$ & 45,2 & $60,0-80,0$ & Rendah \\
Limfosit & $\%$ & 37,3 & $12,0-30,0$ & Tinggi \\
Monosit & $\%$ & 17,5 & $3,0-10,0$ & Tinggi \\
ALT/SGPT & $\mathrm{U} / \mathrm{L}$ & 76 & $8,2-57,3$ & Tinggi \\
Albumin & $\mathrm{d} / \mathrm{dL}$ & 2,2 & $2,6-4,0$ & Rendah \\
Globulin & $\mathrm{g} / \mathrm{dL}$ & 3,4 & $2,7-4,4$ & Normal \\
ALP & $\mathrm{U} / \mathrm{L}$ & 376 & $10,6-100,7$ & Tinggi \\
\hline
\end{tabular}

Keterangan: $\mathrm{WBC}=$ white blood cells, $\mathrm{RBC}=$ red blood cells, $\mathrm{Hb}=$ hemoglobin, $\mathrm{HCT}=$ hematokrit, $\mathrm{MCV}=$ mean corpuscular volume, $\mathrm{MCH}=$ mean cospuscular hemoglobin, $\mathrm{MCHC}=$ mean corpuscular hemoglobin concentration, ALT=alanine aminotransferase, $\mathrm{ALP}=$ alkaline phosphatase

\section{- HASIL DAN PEMBAHASAN}

Berdasarkan anamnesis dan pemeriksaan fisik anjing mengalami odontoma yang kemungkinan disebabkan kurang aseptisnya area mulut anjing tersebut yang ditandai dengan banyaknya karang gigi dan menurut pemilik gigi anjing jarang dibersihkan dan anjing setiap hari diberikan pakan basah sehingga menyebabkan banyaknya karang gigi yang dapat memicu munculnya bakteri pada area mulut, gigi dan gusi. Menurut Nunes et al. (2020) odontoma adalah penyakit yang berhubungan dengan gigi, dimana perubahan tulang divisualisasikan pada mandibula, namun ada kemungkinan juga bisa terdapat pada daerah maksila. Perlu dilakukannya biopsi ataupun pemeriksaan histopatologi untuk mendapatkan diagnosis pasti apakah tumor tersebut bersifat jinak atau ganas meskipun pemeriksaan radiografi (Jaeger et al. 2012) adalah metode diagnostik pilihan karena merupakan media cepat dalam menyajikan temuan karakteristik penyakit.

\section{- SIMPULAN}

Berdasarkan gejala klinis dan pemeriksaan penunjang maka diagnosa untuk anjing Hugo adalah odontoma. Terapi yang dilakukan yaitu bedah ekstirpasi, pencabutan gigi disekitarnya dan pembersihan karang gigi (scalling). Terapi pascabedah yang diberikan yaitu antiseptik, kortikosteroid, dan suplemen. Kasus dapat ditangani dengan baik dan pada hari ke-1 pascabedah, anjing Hugo diperbolehkan pulang karena kondisinya sudah membaik.

\section{- INFORMASI PENULIS}

Penulis untuk Korespondensi

* MAL: arfan_lesmana@ub.ac.id

Departemen Klinik Hewan Pendidikan, Fakultas Kedokteran Hewan, Universitas Brawijaya, Malang, INDONESIA.

\section{- PUSTAKA ACUAN}

Barnes L, Eveson JW, Reichart P, Sidransky D. 2005. WHO Classification of Tumors: Pathology and Genetics of Head and Neck Tumors. Lyon, France: IARC Press.

Jeager F, Alvarenga RL, Lage FO, Reis IA, Leal RM. 2012. Odontoma compost-relato de caso clinico. Revista Portuguesa deEstomatologia Dentária e Cirurgia maxilobucofacial. 53(4):252-257.

Kharbanda OP, Saimbi CS, Kharbanda R. 1986. Odontome: A case report. J Indian Dent Assoc. Jul:58(6):269-271.

Nunes MO. 2020. Odontoma composto-relato de caso. Semana de Pesquisa do Centro Universitário Tiradentes-SEMPESq-Alagoas, (6): 1 . 